\title{
KARAKTERISTIK PELAKU MOBILITAS \\ DI KELURAHAN SUNGAI PIRING KECAMATAN BATANG TUAKA KABUPATEN INDRAGIRI HILIR PROPINSI RIAU
}

\author{
Oleh: \\ Laila Marshelly *,Paus Iskarni**, Febriandi** \\ *Mahasiswa S1 Prodi Pendidikan Geografi**Dosen Jurusan Geografi UNP \\ Email: ilarizani86@gmail.com
}

\begin{abstract}
ABSTRAK
Penelitian ini bertujuan untuk mengetahui tentang : :(1) Karakteristik pelaku mobillitas kepala keluarga laki-laki, (2) Karakteristik pelaku mobillitas kepala keluarga perempuan, (3) Karakteristik pelaku mobillitas istri, (4) Karakteristik pelaku mobillitas anak.Penelitian ini adalah penelitian deskriptif kuantitatif. Penelitian ini dilakukan di Kelurahan Sungai Piring Kecamatan Batang Tuaka Kabupaten Indragiri Hilir Provinsi Riau. Penetapan sampel adalah masyarakat yang ada di Kelurahan Sungai Piring dengan menggunakan teknik proporsional random sampling. Jumlah sampel dalam penelitian ini sebanyak 82 Kepala Keluarga. Teknik pengumpulan data yaitu dengan cara pengisian angket oleh responden. Teknik analisis data yang digunakan yaitu dengan menggunakan persentase, tabulasi menggunakan spss.

Hasil penelitian ini menemukan: (1) Karakteristik pelaku mobilitas kepala keluarga laki-laki berumur 19-60 tahun, jenis pekerjaan dominan adalah petani, tingkat pendidikan umumnya tamat SD. Alasan melakukan mobilitas karena pekerjaan, tujuan mobilitas adalah ladang. Jenis mobilitas adalah mobilitas harian dan mingguan, dengan durasi 5-10 jam, menggunakan sepeda, sepeda motor, jalan kaki, mobil dan kapal, (2) Karakteristik pelaku mobilitas kepala keluarga perempuan berumur 41-50 tahun, pekerjaan paling dominan adalah IRT,tingkat pendidikan umumnya tamat SD. Alasan melakukan mobilitas untuk membeli kebutuhan sehari-hari, tujuan mobilitas pasar. Jenis mobilitas adalah mobilitas harian dan mingguan, dengan durasi 2-8 jam, menggunakan sepeda, sepeda motor dan jalan kaki, (3) Karakteristik pelaku mobilitas istri berumur 20-60 tahun, pekerjaan paling dominan adalah IRT, tingkat pendidikan umumnya tamat SD. Alasan melakukan mobilitas untuk membeli kebutuhan sehari-hari, tujuan mobilitas adalah pasar. Jenis mobilitas adalah mobilitas mingguan, dengan durasi 2-9 jam, menggunakan sepeda, sepeda motor dan jalan kaki, (4) Karakteristik pelaku mobilitas anak berumur 7-40 tahun, pekerjaan paling dominan pelajar, dengan tingkat pendidikan umumnya masih SD dan SMP. Alasan melakukan mobilitas karena pendidikan, dimana tujuan mobilitas adalah sekolah. Jenis mobilitas adalah mobilitas harian, dengan durasi 4-10 jam, menggunakan sepeda, sepeda motor dan jalan kaki.
\end{abstract}

Kata kunci: Mobilitas

\section{PENDAHULUAN}

Pembangunan pada hakikatnya adalah suatu proses kemajuan dan perbaikan terus menerus menuju kepada tercapainya tujuan yang diinginkan. Secara umum, tujuan yang diinginkan. Secara umum, tujuan yang ingin dicapai adalah terciptanya peningkatan kesejahteraan masyarakat secara lebih adil dan merata. Berbagai macam upaya pemerintah untuk 
meningkatkan kesejahteraan masyarakat antara lain dengan melakukan pembangunan sarana dan prasarana fisik. Salah satu pembangunan fisik adalah dengan melakukan pembangunan di bidang transportasi, dimana sarana dan prasarana transportasi akan mendukung dan menunjang pembangunan secara fisik.

Pembangunan transportasi dapat digunakan sebagai sarana untuk mengembangkan dan memajukan daerah terpencil agar dapat menjadi maju. Melalui pengembangan saran dan prasarana transportasi diharapkan daerah dan penduduknya dapat berkembang. Pengembangan sarana dan prasarana transportasi dapat dilakukan dengan pembangunan jalan baru maupun memperbaiki kondisi jalan yang sudah ada.

Jalan adalah prasarana transportasi darat yang meliputi segala bagian jalan, termasuk bangunan pelengkap dan perlengkapannya yang diperuntukkan bagi lalu lintas, yang berada pada permukaan tanah, di atas permukaan tanah, di bawah permukaan tanah dan/atau air, serta di atas permukaan air, kecuali jalan kereta api, jalan lori, dan jalan kabel (Undang-undang Nomor 34 Tahun 2006 tentang jalan).Jaringan jalan merupakan salah satu faktor yang berpengaruh terhadap kelancaran pelayanan umum. Tersedianyan prasarana jalan baik kualitas maupun kuantitas sangat menentukan mudah tidaknya suatu daerah untuk dijangkau (tingkat aksesibilitas). Selain itu tersedianya prasarana transportasi berupa jalan dan alat angkut merupakan salah satu pendorong mobilitas penduduk. Karena dengan adanya prasarana transportasi yang lengkap masyarakat bisa lebih mudah untuk akses keluar daerah untuk meningkatkan ekonomi dan mempermudah orang-orang untuk bekerja dan bersekolah (ejournal.ip. fisip.umul.ac.id)

Beberapa faktor pendorong penduduk untuk melakukan mobilitas adalah untuk memenuhi kebutuhan hidup, pekerjaan, pendidikan dan pelayanan kesehatan, karena pada daerah asal terdapat keterbatasan sarana (pendidikan, lapangan kerja, kesehatan) untuk memenuhi kebutuhan penduduk. Biasanya masyarakat desa akan melakukan mobilitas menuju kota terdekat. Salah satu contoh yaitu Kelurahan Sungai Piring. Penduduk di Kelurahan Sungai Piring melakukan mobilitas menuju kota Tembilahan.

Kelurahan Sungai Piring merupakan ibu kota Kecamatan Batang Tuaka yang terdapat di Kabupaten Indragiri Hilir. Walaupun merupakan pusat kecamatan akses menuju dan dari kelurahan sungai piring masih sulit untuk dijangkau. Untuk keluar dar kelurahan Sungai Piring menuju desa dan kecamatan lain hanya ada satu jalan. keadaan jalan tersebut sudah rusak dan sulit untuk dilalui. Keadaan jalan tersebut tentu saja memperlama waktu perjalanan, serta memperbesar biaya trasnportasi. Hal ini tentu saja akan berpengaruh pada karakteristik pelaku mobilitas di Kelurahan Sungai Piring.

\section{KAJIAN PUSTAKA}

\section{Mobilitas}

Mobilitas adalah suatu perpindahan atau kepergian secara teratur ke suatu tempat untuk bekerja dan dalam satu hari sudah kembali ke rumah, perpindahan semacam ini disebut juga kepergian ulang alik atau commuting (Pardoko,1986:9).

Menurut (Tukiran,2002) mobilitas penduduk adalah perpindahan penduduk 
dari suatu daerah ke daerah lain atau dari satu tempat ke tempat lain, misalnya perpindahan penduduk dari desa ke kota dan sebaliknya, perpindahan penduduk dari provinsi satu ke provinsi lain, dari pulau satu ke pulau lain, dan dari negara satu ke negara lain. Faktor yang menyebabkan seseorang melakukan mobilitas antara lain, yaitu: ekonomi, politik, sosial dan budaya, keamanan, agama dan bencana alam.

Menurut (Ida Bagoes Mantra,2003) mobilitas adalah proses gerak penduduk dari satu wilayah menuju wilayah lain dalam jangka waktu tertentu. Sedangkan menurut (Sumaatmadja, 1981:147) bahwa:

"Mobilitas adalah pergerakan penduduk dari satu tempat ke tempat lain, baik untuk memenuhi kebutuhan ekonomi maupun kebutuhan sosial lainnya. Tingkah laku manusia dalam bentuk perpindahan tadi, erat hubungannya dengan faktorfaktor geografi pada ruang yang bersangkutan. Faktor-faktor tersebut meliputi faktor fisis dan non fisis. Bentuk permukaan bumi, elevasi, vegetasi dan keadaan cuaca merupakan faktor fisis yang mempengaruhi gerak perpindahan yang dilakukan manusia. Alat transportasi, kegiatan ekonomi, biaya transportasi, kondisi jalan dan kondisi sosial budaya setempat merupakan faktor non fisis yang mendorong manusia untuk beranjak dari tempat asalnya."

Mobilitas dapat diartikan sebagai tingkat kelancaran perjalanan, dan dapat diukur melalui banyaknya perjalanan (pergerakan) dari satu lokasi ke lokasi lain sebagai akibat tingginya tingkat akses antara lokasi-lokasi tersebut (Fidel Miro, 2002:22)
Faktor-faktor pendorong mobilitas:

a. Faktor ekonomi

Mobilitas penduduk diantaranya terjadi karena ketimpangan pembangunan dan ketidakmerataan berbagai fasilitas sosial ekonomi antara satu wilayah dengan wilayah lain. Hal ini sebagai mana dikemukakan oleh Tadoro yang dikuti dalam Mantra(1985:18) bahwa motif utama seseorang melakukan migrasi adalah ekonomi.

b. Faktor kekerabatan

Keputusan individu dalam menentukan daerah tujuan dipengaruhi oleh informasi yang diterima tentang daerah tujuan. Informasi tersebut biasanya diperoleh dari sanak/keluarga yang sebelumnya telah melakukan mobilitas.

c. Faktor pendidikan

Volume migrasi dalam satu wilayah tertentu berkembang sesuai denga tingkat perkembangan dari keanekaragaman dalam satu wilayah. Keanekaragaman dalam satu wilayah merupakan daya tarik bagi penduduk dari berbagai jenis pendidikan dan tingkat pendidikan. Semakin tinggi tingkat pendidikan semakin maju motivasi penduduk untuk pergi kedaerah lain.

d. Faktor fasilitas transportasi

$\begin{array}{lcr}\text { Peningkatan } & \text { jalan desa } & \text { dapat } \\ \text { meningkatkan } & \text { pendapatan } & \text { desa., } \\ \text { mendorong } & \text { dan } & \text { memperluas } \\ \text { komersialisasi } & \text { pertanian } & \text { serta } \\ \text { meningkatkan } & \text { produksi } & \text { pertanian. }\end{array}$ Dengan demikian orang-orang desa akan semakin sering melakukan perjalanan ke kota dengan ongkos murah. Migrasi desa kota akan semakin meningkat, karena integrasi desa kota semakin baik. 
Pola mobilitas penduduk secara garis besar ada dua :

a. Mobilitas penduduk tidak permanen

Mobilitas penduduk tidak permanen adalah perpindahan penduduk dari satu daerah ke daerah lain yang tidak bertujuan untuk menetap, hanya bersifat sementara. Perpindahan penduduk yang bersifat sementara disebut mobilitas serkuler. Mobilitas serkuler terdiri atas :

1) Mobilitas ulang alik alik adalah gerak penduduk dari daerah asal menuju ke daerah tujuan dalam batas waktu tertentu dan kembali ke daerah asal pada hari itu juga.

2) Mobilitas bermusim. Perpindahan penduduk secara bermusim dan bersifat sementara, misalnya para buruh tani yang selama kegiatan pertanian di pedesaan mereka tinggal di desa dan ketika tidak ada kegiatan pertanian mereka tinggal di tempat lain.

b. Mobilitas penduduk permanen

Mobilitas penduduk permanen disebut juga migrasi. Migrasi adalah perpindahan penduduk dari suatu tempat ke tempat lain melampaui batas negara atau batas administrasi untuk tujuan menetap. Migrasi dapat dibedakan menjadi dua yaitu

1) Migrasi internasional, adalah perpindahan penduduk dari satu negara ke negara lain. Meliputi imigrasi, emigrasi, dan remigrasi.

2) Migrasi nasional, adalah perpindahan penduduk dari satu daerah ke daerah lain dalam satu wilayah negara. Pola migrasi nasional adalah urbanisasi, transmigrasi, ruralisasi.
Tabel 1. Batasan Ruang dan Waktu dalam mobilitas Penduduk

\begin{tabular}{|c|c|c|}
\hline $\begin{array}{c}\text { Bentuk } \\
\text { Mobilitas }\end{array}$ & $\begin{array}{l}\text { Batasan } \\
\text { Wilayah }\end{array}$ & $\begin{array}{c}\text { Batas } \\
\text { Waktu }\end{array}$ \\
\hline $\begin{array}{l}\text { Ulang alik } \\
\text { (Commuting) }\end{array}$ & $\begin{array}{l}\text { Dukuh/ } \\
\text { Dusun }\end{array}$ & $\begin{array}{l}\text { Enam jam } \\
\text { atau lebih } \\
\text { dan kembali } \\
\text { pada hari } \\
\text { yang sama }\end{array}$ \\
\hline
\end{tabular}

$\begin{array}{lll}\text { Menginap } & \begin{array}{l}\text { Dukuh/ } \\ \text { Dusun }\end{array} & \begin{array}{l}\text { Lebih dari } \\ \text { satu hari, } \\ \text { tetapi kurang } \\ \text { dari enam } \\ \text { bulan }\end{array} \\ \text { Menetap } & \text { Dukuh/ } & \begin{array}{l}\text { Enam buan } \\ \text { atau lebih } \\ \text { menetap di } \\ \text { daerah } \\ \text { tujuan }\end{array}\end{array}$

Sumber : Mantra (2013)

\section{Transportasi}

Transportasi berasal dari kata Latin Transportare, Trans artinya seberang, antar atau kesebelah dan portare artinya mengangkut. Jadi transportasi itu menurut asal kata ini berarti mengangkut ke seberang. Artinya suatu kegiatan yang memindahkan barang atau orang dari satu tempat ke tempat lainnya (Kamaluddin, 1987).

M.Siregar
pandangan yang sama bahwa
pengangkutan diartikan sebagai usaha
pemindahan barang dan manusia dari
tempat asal ke tempat tujuan. Lebih luas
Siregar melihat terdapat tiga hal penting
dalam transportasi yaitu:
a. Barang atau muatan
b. Kendaraan
c. Jalan sebagai prasarana 
M.E.Eliot

Hurst

(1974)

mengemukakan bahwa transportasion is measure of the relation between areas (transportasi adalah suatu kegiatan yang menghubungkan antara daerah dengan daerah lain). Hurst juga mengemukakan bahwa kegiatan transportasi muncul karena ada tiga fakto geografis antara lain:

a. Jarak (distance)

b. Melengkapi kebutuhan (complementary)

c. Kesempatan untuk intervensi

(intervening opportunity)

Peranan utama transportasi adalah menunjang mobilitas baik barang atau manusia yang merupakan bagian dari kehidupan, samakin baik sistem transportasi semakin baik pula kehidupan penduduk. Mobilitas penduduk dan persebarannya mempengaruhi peningkatan sarana dan prasarana transportasi. Sehingga dengan alat yang sangat modern orang berusaha membangun jalan-jalan baru baik di daerah maupun di kota.

Sistem transportasi merupakan gabungan elemen-elemen atau komponenkomponen :

a. Prasarana (jalan dan terminal)

b. Sarana (kendaraan)

c. Sistem pengoperasian (yang mengkoordinasikan komponen sarana dan prasarana (Miro, 2002:15).

Ini berarti bahwa pengembangan sistem transportasi untuk mendukung kelancaran moilitas manusia antara tata guna lahan dalam memenuhi kebutuhan kehidupan ekonominya adalah mengembangkan salah satu komponen elemen tersebut .

\section{METODE PENELITIAN}

Jenis penelitian Deskriptif

Kuantitatif. Populasi yang diambil pada penelitian ini adalah seluruh rumah tangga yang berada di Kelurahan Sungai Piring yang berjumlah 1026 rumah tangga. Sampel dalam penelitian ini diambil dengan teknik proportionalrandom sampling dimana jumlah populasi dalam penelitian ini sebanyak $82 \mathrm{kk}$.

Jenis data yaitu, data primer berupa data yang diperoleh dari observasi lapangan dan pengisian angket. Data skunder berupa data yang diperoleh melalui buku - buku perpustakaan, karya ilmiah, Badan Pusat Statistik, dan Kantor Lurah, Kantor Camat, Dinas Bina Marga.

Teknik pengumpulan data dengan melakukan wawancara, observasi lapangan dan pengisian angket. Analisa data yang digunakan untuk menganalisa data dalam penelitian ini adalah dengan teknik prosentase $(\mathrm{P}=\mathrm{f} / \mathrm{N} \times 100)$

\section{HASIL DAN PEMBAHASAN}

\section{Karakteristik pelaku mobilitas Kepala} Keluarga Laki-laki

Rentang umur adalah 19 tahun sampai 60 tahun. Yang didominasi oleh umur 41 tahun sampai 50 tahun Pekerjaan pelaku mobilitas kepala keluarga laki-laki adalah petani, pedagang, nelayan, pegawai negeri sipil, dan wiraswasta. Dimana pekerjaan yang paling dominan adalah sebagai petani.

Tabel 1. Karakteristik umur pelaku mobilitas untuk laki-laki

\begin{tabular}{|l|l|c|c|}
\hline \multirow{2}{*}{ No } & \multirow{2}{*}{ Umur } & \multicolumn{2}{|c|}{ Kepala Keluarga } \\
\cline { 3 - 4 } & & $\mathrm{f}$ & $\%$ \\
\hline 1 & $19-30$ & 6 & 8 \\
\hline 2 & $31-40$ & 28 & 37,3 \\
\hline 3 & $41-50$ & 29 & 38,7 \\
\hline 4 & $51-60$ & 12 & 16 \\
\hline \multicolumn{2}{|l}{ Jumlah } & 75 & 100 \\
\hline
\end{tabular}

Sumber: Olahan data primer 
Tabel 2. Karakteristik pekerjaan pelaku mobilitas untuk laki-laki

\begin{tabular}{|c|c|c|c|}
\hline \multirow{2}{*}{$\begin{array}{l}\mathbf{N} \\
\mathbf{o}\end{array}$} & \multirow{2}{*}{ Pekerjaan } & \multicolumn{2}{|c|}{$\begin{array}{c}\text { Kepala } \\
\text { Keluaraga Lk }\end{array}$} \\
\hline & & $\mathbf{f}$ & $\%$ \\
\hline 1 & Nelayan & 3 & 4 \\
\hline 2 & Petani & 41 & 54,7 \\
\hline 3 & Pedagang & 10 & 13,3 \\
\hline 4 & PNS & 9 & 12 \\
\hline 5 & Pekerja Lepas & 1 & 1,3 \\
\hline 6 & Wiraswasta & 11 & 14,7 \\
\hline & Jumlah & 75 & 100 \\
\hline
\end{tabular}

Sumber: Olahan data primer

Tingkat pendidikan pelaku mobilitas sebagai kepala keluarga beragam yaitu tamat SD, tamat SMP, tamat SMA, dan tamat PT. Tingkat pendidikan paling dominan adalah tamat SD.

Tabel 3. Karakteristik pendidikan pelaku mobilitas untuk laki-laki

\begin{tabular}{|c|c|c|c|}
\hline \multirow{2}{*}{$\begin{array}{c}\text { N } \\
\text { o }\end{array}$} & \multirow{2}{*}{ Pendidikan } & \multicolumn{2}{|c|}{$\begin{array}{c}\text { Kepala } \\
\text { Keluarag Lk }\end{array}$} \\
\cline { 3 - 4 } & & $\mathbf{f}$ & $\mathbf{\%}$ \\
\hline 1 & Tamat SD & 46 & 61,3 \\
\hline 2 & Tamat SMP & 4 & 5,3 \\
\hline 3 & Tamat SMA & 15 & 20 \\
\hline 4 & Tamat PT & 10 & 13,4 \\
\hline \multicolumn{2}{c}{ Jumlah } & 75 & 100 \\
\hline
\end{tabular}

Sumber: Olahan data primer

Alasan kepala keluarga laki-laki melakukan mobilitas adalah untuk pekerjaan, pendidikan dan memenuhi kebutuhan seharu-hari.

Dimana arah tujuan mobilitasnya menuju ladang, bengkel, dinas pemerintahan, sekolah, kilang padi, puskesmas dan Tembilahan. Arah tujuan mobilitas paling dominan adalah ladang/kebun, karena pekerjaan kepala keluarga laki-laki umumnya adalah petani
Tabel 4. Tujuan mobilitas

\begin{tabular}{|c|c|c|c|}
\hline \multirow[t]{2}{*}{$\mathbf{N}$} & \multirow[t]{2}{*}{ Pendidikan } & \multicolumn{2}{|c|}{$\begin{array}{c}\text { Kepala } \\
\text { Keluarag Lk }\end{array}$} \\
\hline & & f & $\%$ \\
\hline 1 & Ladang & 41 & 54,7 \\
\hline 2 & Bengkel & 3 & 4 \\
\hline 3 & Concong & 3 & 4 \\
\hline 4 & Kantor/dinas & 1 & 1,3 \\
\hline 5 & Sekolah & 8 & 10.7 \\
\hline 6 & Kilang padi & 3 & 4 \\
\hline 7 & Puskesmas & 2 & 2,7 \\
\hline 8 & Tembilahan & 14 & 18,6 \\
\hline & Jumlah & 75 & 100 \\
\hline
\end{tabular}

Sumber: Olahan data primer

Jenis mobilitas yang dilakukan adalah mobilitas harian dan moilitas minguan. Hal ini karena untuk kepala keluarga yang bekerja sebagai petani dan PNS mereka umumnya melakukan mobilitas hampir setiap hari, sedangkan yang bekerja sebagai pedagang dan nelayan melakukan mobilitas hanya 3-4 kali dalam seminggu.

Tabel 5. Jenis mobilitas yang dilakukan

\begin{tabular}{|c|l|c|c|}
\hline \multirow{2}{*}{$\begin{array}{c}\text { N } \\
\mathbf{0}\end{array}$} & \multirow{2}{*}{ Jenis } & \multicolumn{2}{|c|}{$\begin{array}{c}\text { Kepala Keluarga } \\
\text { Laki-laki }\end{array}$} \\
\cline { 3 - 4 } & & $\mathbf{f}$ & $\mathbf{\%}$ \\
\hline 1 & Harian & 58 & 77,3 \\
\hline 2 & Mingguan & 17 & 22,7 \\
\hline \multicolumn{2}{|c|}{ Jumlah } & 75 & 100 \\
\hline
\end{tabular}

Sumber: Olahan data primer

Durasi mobilitas kepala keluarga laki-laki dalam melakukan mobilitas yaitu selama 5 jam sampai 10 jam, menggunakan transportasi berupa sepeda, sepeda motor, mobil, kapal dan jalan kaki. Durasi yang paling dominan yaitu sekitar 10 jam. Hal ini karena umumnya kepala keluarga yang bekerja sebagai petani berada di ladang/kebun mereka selama 10 jam. 
Tabel 6. Sarana Transportasi yang digunakan

\begin{tabular}{|c|c|c|c|}
\hline \multirow{2}{*}{$\begin{array}{l}\mathbf{N} \\
\mathbf{o}\end{array}$} & \multirow{2}{*}{ Pendidikan } & \multicolumn{2}{|c|}{$\begin{array}{c}\text { Kepala } \\
\text { Keluarag Lk }\end{array}$} \\
\hline & & $\mathbf{f}$ & $\%$ \\
\hline 1 & Jalan kaki & 20 & 26,7 \\
\hline 2 & Sepeda & 9 & 12 \\
\hline 3 & Sepeda motor & 40 & 53,3 \\
\hline 4 & Mobil & 3 & 4 \\
\hline 5 & Kapal & 3 & 4 \\
\hline & Jumlah & 75 & 100 \\
\hline
\end{tabular}

Sumber: Olahan data primer

\section{Karakteristik Pelaku Mobilitas Kepala Keluarga Perempuan}

Dalam penelitian ini karakteristik pelaku mobilitas sebagai kepala keluarga perempuan, dilihat dari umur berada pada rentang umu 41 tahun sampai 50 tahun.

Tabel 7. Karakteristik umur pelaku mobilitas untuk Perempuan

\begin{tabular}{|l|l|c|c|}
\hline \multirow{2}{*}{ No } & \multirow{2}{*}{ Umur } & \multicolumn{2}{|c|}{ Kepala Keluarga } \\
\cline { 3 - 4 } & & F & $\%$ \\
\hline 1 & $19-30$ & - & - \\
\hline 2 & $31-40$ & - & - \\
\hline 3 & $41-50$ & 6 & 100 \\
\hline 4 & $51-60$ & - & - \\
\hline \multicolumn{2}{|l}{ Jumlah } & 6 & 100 \\
\hline
\end{tabular}

Sumber: Olahan data primer

Dengan jenis pekerjaan sebagai ibu rumah tangga, pedagang, PNS dan petani. Pekerjaan paling dominan yaitu sebagai ibu rumah tangga.

Tabel 8. Karakteristik pekerjaan pelaku mobilitas untuk Perempuan

\begin{tabular}{|l|l|c|c|}
\hline \multirow{2}{*}{ No } & \multirow{2}{*}{ Umur } & \multicolumn{2}{|c|}{ Kepala Keluarga } \\
\cline { 3 - 4 } & & F & $\%$ \\
\hline 1 & IRT & 2 & 33,3 \\
\hline 2 & Pedagang & 1 & 16,7 \\
\hline 3 & PNS & 1 & 16,7 \\
\hline 4 & Petani & 2 & 33,3 \\
\hline \multicolumn{2}{|l}{ Jumlah } & 6 & 100 \\
\hline
\end{tabular}

Sumber: Olahan data primer

Tingkat pendidikan pelaku mobilitas kepala keluarga perempuan yaitu tamat
SD, tamat SMP, tamat SMA, dan tamat PT. Dimana tingkat pendidikan dominan adalahtamat SD.

Tabel 9. Karakteristik pendidikan pelaku mobilitas untuk Perempuan

\begin{tabular}{|c|l|c|c|}
\hline \multirow{2}{*}{ No } & \multirow{2}{*}{ Pendidikan } & \multicolumn{2}{|c|}{$\begin{array}{c}\text { Kepala } \\
\text { Keluarga Pr }\end{array}$} \\
\cline { 3 - 4 } & & $\mathbf{f}$ & $\mathbf{\%}$ \\
\hline 1 & Tamat SD & 5 & 83,3 \\
\hline 2 & Tamat SMP & - & - \\
\hline 3 & Tamat SMA & - & - \\
\hline 4 & Tamat PT & 1 & 16,7 \\
\hline \multicolumn{2}{|c}{ Jumlah } & 6 & 100 \\
\hline
\end{tabular}

Sumber: Olahan data primer

Alasan kepala keluarga perempuan melakukan mobilitas adalah untuk pekerjaan dan memenuhi kebutuhan sehari-hari.

Tabel 10. Karakteristik pelaku mobilitas

\begin{tabular}{|c|l|c|c|}
\hline \multirow{2}{*}{$\begin{array}{c}\text { N } \\
\text { o }\end{array}$} & \multirow{2}{*}{ Pelaku } & \multicolumn{2}{c|}{ Kepala } \\
& & Keluarga Pr \\
\cline { 3 - 4 } & f & \% \\
\hline 1 & Pekerjaan & 4 & 66,7 \\
\hline 2 & Pendidikan & - & - \\
\hline 3 & $\begin{array}{l}\text { Membeli } \\
\text { kebutuhan }\end{array}$ & 2 & 33,3 \\
\hline \multicolumn{2}{|c|}{ Jumlah } & 6 & 100 \\
\hline
\end{tabular}

Sumber: Olahan data primer

Arah tujuan mobilitas kepala keluarga perempuan adalah ladang, pasar dan sekolah, dimana tujuan mobilitas yang paling dominan adalah ke ladang/kebun.

Tabel 11. Tujuan pelaku mobilitas

\begin{tabular}{|c|l|c|c|}
\hline \multirow{2}{*}{ No } & \multirow{2}{*}{ Tujuan } & \multicolumn{2}{|c|}{$\begin{array}{c}\text { Kepala } \\
\text { Keluarga Pr }\end{array}$} \\
\cline { 3 - 4 } & & $\mathbf{f}$ & $\mathbf{\%}$ \\
\hline 1 & Ladang & 2 & 33,3 \\
\hline 2 & Pasar & 2 & 33,3 \\
\hline 3 & Tembilahan & 1 & 16,7 \\
\hline 4 & Sekolah & 1 & 16,7 \\
\hline \multicolumn{2}{|c|}{ Jumlah } & 6 & 100 \\
\hline
\end{tabular}

Sumber: Olahan data primer

Jenis mobilitas yang dilakukan kepala keluarga perempuan adalah mobilitas mingguan dan harian. Karena 
kepala keluarga perempua yang bekerja sebagai PNS dan petani akan melakukan mobilitas setiap hari, sedangkan yang bekerja sebagai ibu rumah tangga melakukan mobilitas 1-2 kali seminggu untuk membeli kebutuhan sehari-hari.

Durasi mobilitas yang dilakukan kepala keluarga perempuan berkisar antara 2 sampai 7 jam. Biasanya durasi mobilitas 2 jam dilakukan penduduk yang bekerja sebagai ibu rumah tangga untuk membeli kebutuhan sehari-hari ke pasar.

Tabel 12. Durasi waktu mobilitas

\begin{tabular}{|c|l|c|c|}
\hline \multirow{2}{*}{$\begin{array}{c}\text { N } \\
\text { o }\end{array}$} & \multirow{2}{*}{ Durasi } & \multicolumn{2}{c|}{$\begin{array}{c}\text { Kepala } \\
\text { Keluarga Pr }\end{array}$} \\
\cline { 3 - 4 } & & $\mathbf{f}$ & $\mathbf{\%}$ \\
\hline 1 & 2 jam & 2 & 33,3 \\
\hline 2 & 6 jam & 1 & 16,7 \\
\hline 3 & 7 jam & 2 & 33,3 \\
\hline 4 & 8 jam & 1 & 16,7 \\
\hline \multicolumn{2}{|c|}{ Jumlah } & 6 & 100 \\
\hline
\end{tabular}

Sumber: Olahan data primer

Sarana transportasi yang digunakan kepala keluarga perempuan untuk melakukan mobilitas adalah jalan kaki, sepeda dan sepeda motor. Dimana sarana transportasi yang dominan digunakan adalah dengan berjalan kaki.

Tabel 13. Sarana transportasiyang digunakan

\begin{tabular}{|c|c|c|c|}
\hline \multirow{2}{*}{$\begin{array}{l}\mathbf{N} \\
\mathbf{o}\end{array}$} & \multirow{2}{*}{$\begin{array}{c}\text { Sarana } \\
\text { Transportasi }\end{array}$} & \multicolumn{2}{|c|}{$\begin{array}{c}\text { Kepala Keluarga } \\
\text { Perempuan }\end{array}$} \\
\hline & & f & $\%$ \\
\hline 1 & Jalan kaki & 2 & 33,3 \\
\hline 2 & Sepeda & 1 & 16,7 \\
\hline 3 & Sepeda motor & 2 & 33,3 \\
\hline 4 & Mobil & 1 & 16,7 \\
\hline & Jumlah & 6 & 100 \\
\hline
\end{tabular}

Sumber: Olahan data primer

\section{Karakteritik Pelaku Mobilitas Istri}

Dalam penelitian ini karakteritik istri yang melakukan mobilitas berada pada rentang usia 20 tahun sampai 60 tahun. Dengan rentang usia dominan adalah 31 tahun sampai 40 tahun.
Tabel 14. Karakteristik umur

\begin{tabular}{|c|c|c|c|}
\hline \multirow{2}{*}{$\begin{array}{l}\mathbf{N} \\
\mathbf{0}\end{array}$} & \multirow{2}{*}{ Umur } & \multicolumn{2}{|c|}{ Istri } \\
\hline & & $\mathbf{f}$ & $\%$ \\
\hline 1 & $20-30$ & 13 & 18 \\
\hline 2 & $31-40$ & 38 & 52,8 \\
\hline 3 & $41-50$ & 12 & 16,7 \\
\hline 4 & $51-60$ & 9 & 12,5 \\
\hline & Jumlah & 72 & 100 \\
\hline
\end{tabular}

Sumber: Olahan data primer

Jenis pekerjaan istri yang melakukan mobilitas yaitu sebagai ibu rumah tangga, pegawai negeri sipil, pedagang, pegawai swasta, petani dan wiraswasta. Dimana pekerjaan istri yang paling dominan adalah sebagai ibu rumah tangga.

Tabel 15. Karakteristik pekerjaan

\begin{tabular}{|c|l|c|c|}
\hline \multirow{2}{*}{$\begin{array}{c}\text { N } \\
\text { o }\end{array}$} & \multirow{2}{*}{ Pekerjaan } & \multicolumn{2}{|c|}{ Istri } \\
\cline { 3 - 4 } & & $\mathbf{f}$ & $\mathbf{\%}$ \\
\hline 1 & Ibu RT & 52 & 72,2 \\
\hline 2 & PNS & 3 & 4,2 \\
\hline 3 & Pedagang & 3 & 4,2 \\
\hline 4 & Pegawai Swasta & 5 & 7 \\
\hline 5 & Petani & 7 & 9,7 \\
\hline 6 & Wiraswasta & 2 & 2,7 \\
\hline \multicolumn{2}{|c|}{ Jumlah } & 72 & 100 \\
\hline
\end{tabular}

Sumber: Olahan data primer

Tingkat pendidikan istri yang melakukan mobilitas yaitu mulai dari tamat SD, tamat SMP, tamat SMA, dan tamat PT. Pendidikan istri yang melakukan mobilitas paling dominan adalah tamat SD.

Tabel 16. Pendidikan terakhir

\begin{tabular}{|c|l|c|c|}
\hline N & \multirow{2}{*}{ Pendidikan } & \multicolumn{2}{|c|}{ Istri } \\
\cline { 3 - 4 } o & & $\mathbf{f}$ & $\mathbf{\%}$ \\
\hline 1 & Tamat SD & 43 & 59,8 \\
\hline 2 & Tamat SMP & 15 & 20,9 \\
\hline 3 & Tamat SMA & 10 & 13,8 \\
\hline 4 & Tamat PT & 4 & 5,5 \\
\hline \multicolumn{2}{|c|}{ Jumlah } & 72 & 100 \\
\hline
\end{tabular}

Sumber: Olahan data primer

Alasan istri melakukan mobilitas karena alasan pekerjaan dan membeli kebutuhan sehari-hari. Alasan yang paling dominan adalah untuk membeli kebutuhan sehari-hari. karena pekerjaan istri yang paling dominan adalah sebagai ibu rumah tangga 
Tabel 17. Alasan Melakukan mobilitas

\begin{tabular}{|c|l|c|c|}
\hline \multirow{2}{*}{$\mathbf{N}$} & \multirow{2}{*}{ Alasan } & \multicolumn{2}{|c|}{ Istri } \\
\cline { 3 - 4 } o & \multicolumn{1}{|c|}{$\mathbf{f}$} & $\mathbf{\%}$ \\
\hline 1 & Pekerjaan & 20 & 27,7 \\
\hline 2 & Pendidikan & - & - \\
\hline 3 & $\begin{array}{l}\text { Membeli } \\
\text { kebutuhan }\end{array}$ & 52 & 72,3 \\
\hline \multicolumn{2}{|c|}{ Jumlah } & 72 & 100 \\
\hline
\end{tabular}

Sumber: Olahan data primer

Arah tujuan istri yang melakukan mobilitas beragam. Mulai dari menuju ladang/kebun, pasar, puskesmas dan sekolah. Dimana arah tujuan mobilitas paling dominan menuju pasar, hal ini tentu saja karena umumnya alasan istri melakukan mobilitas untuk membeli kebutuhan sehari-hari.

Tabel 18. Tujuan Melakukan mobilitas

\begin{tabular}{|c|l|c|c|}
\hline \multirow{2}{*}{$\begin{array}{c}\text { N } \\
\mathbf{0}\end{array}$} & \multirow{2}{*}{ Tujuan } & \multicolumn{2}{|c|}{ Istri } \\
\cline { 3 - 4 } & & $\mathbf{f}$ & $\mathbf{\%}$ \\
\hline 1 & Kantor lurah & 1 & 1,4 \\
\hline 2 & Ladang & 7 & 9,7 \\
\hline 3 & Pasar & 48 & 66,7 \\
\hline 4 & Puskesmas & 2 & 2,8 \\
\hline 5 & Sekolah & 8 & 11,1 \\
\hline 6 & Tembilahan & 6 & 8,3 \\
\hline \multicolumn{2}{|c|}{ Jumlah } & 72 & 100 \\
\hline
\end{tabular}

Sumber: Olahan data primer

Jenis mobilitas yang dilakukan istri adalah mobilitas mingguan dan harian. Jenis mobilitas yang paling dominan adalah mobilitas mingguan. Hal ini karena untuk membeli kebutuhan sehari-hari yang lengkap pasar nya hanya ada satu kali dalam seminggu. Jadi istri yang bekerja sebagai ibu rumah tangga pasti melakukan minimal mobilitas sekali dalam seminggu.

Tabel 19. Jenis mobilitas

\begin{tabular}{|c|l|c|c|}
\hline \multirow{2}{*}{ No } & \multirow{2}{*}{ Jenis } & \multicolumn{2}{|c|}{ Istri } \\
\cline { 3 - 4 } & & f & \% \\
\hline 1 & Harian & 18 & 25 \\
\hline 2 & Mingguan & 54 & 75 \\
\hline \multicolumn{2}{|c|}{ Jumlah } & 72 & 100 \\
\hline
\end{tabular}

Sumber: Olahan data primer
Durasi mobilitas yang dilakukan istri berkisar antara 2 jam hingga 9 jam. Durasi yang paling dominan adalah selama 2 jam.

Tabel 20. Durasi mobilitas

\begin{tabular}{|c|c|c|c|}
\hline \multirow{2}{*}{ No } & \multirow{2}{*}{ Jenis } & \multicolumn{2}{|c|}{ Istri } \\
\hline & & f & $\%$ \\
\hline 1 & 2 jam & 38 & 52,7 \\
\hline 2 & 2,5 jam & 2 & 2,8 \\
\hline 3 & 3 jam & 6 & 8,3 \\
\hline 4 & 4 jam & 2 & 2,8 \\
\hline 5 & 6 jam & 7 & 9,7 \\
\hline 6 & 7 jam & 10 & 13,8 \\
\hline 7 & 8 jam & 5 & 6,9 \\
\hline 8 & 9 jam & 2 & 2,8 \\
\hline & Imlah & 72 & 100 \\
\hline
\end{tabular}

Sumber: Olahan data primer

Transportasi yang digunakan adalah jalan kaki, sepeda dan sepeda motor. Dimana istri sebagai pelaku mobilitas lebih banyak melakukan mobilitas dengan berjalan kaki.

Tabel 21. Alasan Melakukan mobilitas

\begin{tabular}{|c|l|c|c|}
\hline \multirow{2}{*}{$\begin{array}{c}\text { N } \\
\text { o }\end{array}$} & \multirow{2}{*}{ Alasan } & \multicolumn{2}{|c|}{ Istri } \\
\cline { 3 - 4 } 1 & Jalan kaki & 58 & $\mathbf{\%}$ \\
\hline 2 & Sepeda & 4 & 5,5 \\
\hline 3 & Sepeda motor & 10 & 14 \\
\hline \multicolumn{2}{|c|}{ Jumlah } & 72 & 100 \\
\hline
\end{tabular}

Sumber: Olahan data primer

\section{Karakteritik Pelaku Mobilitas Anak}

Karakteritik pelaku mobilitas anak dilihat dari rentang umur, anak yang melakukan mobilitas berumur 7 tahun sampai 40 tahun. Rentang umur yang paling dominan adalah pada rentang umur 7 tahun sampai 18 tahun. Hal ini karena anak pada usia segitu adalah anak usia sekolah.

Tabel 22. Umur Melakukan mobilitas

\begin{tabular}{|c|c|c|c|}
\hline \multirow{2}{*}{ No } & \multirow{2}{*}{ Umur } & \multicolumn{2}{|c|}{ Anak } \\
\cline { 3 - 4 } & & $\mathbf{f}$ & \% \\
\hline 1 & $7-12$ & 25 & 37,9 \\
\hline 2 & $13-18$ & 29 & 43,9 \\
\hline 3 & $19-40$ & 12 & 18,2 \\
\hline \multicolumn{2}{|c|}{ Jumlah } & 66 & 100 \\
\hline
\end{tabular}

Sumber: Olahan data primer 
Tingkat pendidikan anak yang melakukan mobilitas beragam mulai dari masih SD hingga masih kuliah dan tamat SD hingga tamat PT, yang paling dominan adalah masih SD dan masih SMP.

Tabel 23. Pendidikan pelaku mobilitas

\begin{tabular}{|c|c|c|c|}
\hline & \multirow{2}{*}{ Pendidikan } & \multicolumn{2}{|c|}{ Anak } \\
\hline & & f & $\%$ \\
\hline 1 & SD & 22 & 33,3 \\
\hline 2 & SMP & 22 & 33,3 \\
\hline 3 & SMA/SMK & 10 & 15,1 \\
\hline 4 & Kuliah & 1 & 1,5 \\
\hline 5 & Tamat SD & 5 & 7,5 \\
\hline 6 & Tamat SMP & 1 & 1,5 \\
\hline 7 & Tamat SMA & 2 & 3 \\
\hline 8 & Tamat PT & 3 & 4,5 \\
\hline & Jumlah & 66 & 100 \\
\hline
\end{tabular}

Sumber: Olahan data primer

Jenis pekerjaan anak yang melakukan mobilitas adalah sebagai pelajar, petani, nelayan, mahasiswa, pegawai swasta dan pegawai honor.

Tabel 24. Pekerjaan pelaku mobilitas

\begin{tabular}{|c|c|c|c|}
\hline \multirow{2}{*}{ No } & \multirow{2}{*}{ Pekerjaan } & \multicolumn{2}{|c|}{ Anak } \\
\hline & & f & $\%$ \\
\hline 1 & Nelayan & 1 & 1,5 \\
\hline 2 & Guru honor & 1 & 1,5 \\
\hline 3 & Pelajar & 54 & 75 \\
\hline 4 & Mahasiswa & 1 & 1,5 \\
\hline 5 & Pegawai swasta & 3 & 4,1 \\
\hline 6 & Petani & 5 & 6,9 \\
\hline 7 & Wiraswasta & 1 & 1,5 \\
\hline & Jumlah & 66 & 100 \\
\hline
\end{tabular}

Sumber: Olahan data primer

Alasan anak melakukan mobilitas adalah untuk pekerjaan dan pendidikan, tapi didominasi anak yang melakukan mobilitas karena alasan pendidikan

Tabel 25. Alasan Melakukan mobilitas

\begin{tabular}{|c|c|c|c|}
\hline \multirow{2}{*}{ No } & \multirow{2}{*}{ Umur } & \multicolumn{2}{|c|}{ Anak } \\
\cline { 3 - 4 } & & $\mathbf{f}$ & \% \\
\hline 1 & Pendidikan & 55 & 83,3 \\
\hline 2 & Pekerjaan & 11 & 16,7 \\
\hline \multicolumn{2}{|c|}{ Jumlah } & 66 & 100 \\
\hline
\end{tabular}

Sumber: Olahan data primer
Arah tujuan mobilitas beragam, mulai dari menuju sekolah, kampus, ladang dan dinas sosial. Namun didominasi oleh anak yang melakukan mobilitas menuju sekolah.

Tabel 26. Tujuan mobilitas

\begin{tabular}{|c|c|c|c|}
\hline & \multirow{2}{*}{ Pendidikan } & \multicolumn{2}{|c|}{ Anak } \\
\hline & & f & $\%$ \\
\hline 1 & SD & 22 & 33,3 \\
\hline 2 & SMP & 22 & 33,3 \\
\hline 3 & SMA/SMK & 10 & 15,1 \\
\hline 4 & Kuliah & 1 & 1,5 \\
\hline 5 & Tamat SD & 5 & 7,5 \\
\hline 6 & Tamat SMP & 1 & 1,5 \\
\hline 7 & Tamat SMA & 2 & 3 \\
\hline 8 & Tamat PT & 3 & 4,5 \\
\hline & Jumlah & 66 & 100 \\
\hline
\end{tabular}

Sumber: Olahan data primer

Jenis mobilitas paling dominan adalah mobilitas harian . hal ini karena anak yang pergi sekolah umumnya melakukan mobilitas hampir setiap hari.

Tabel 27. Alasan Melakukan mobilitas

\begin{tabular}{|c|c|c|c|}
\hline \multirow{2}{*}{ No } & \multirow{2}{*}{ Umur } & \multicolumn{2}{|c|}{ Anak } \\
\cline { 3 - 4 } & & $\mathbf{f}$ & \% \\
\hline 1 & Harian & 62 & 93,9 \\
\hline 2 & Mingguan & 4 & 6,1 \\
\hline & Jumlah & 66 & 100 \\
\hline
\end{tabular}

Sumber: Olahan data primer

Durasi mobilitas umunya melakukan mobilitas 4 sampai 5 jam. Sedangkan yang masih SMP dan SMA melakukan mobilitas hingga 6-7 jam.

Tabel 28. Pekerjaan pelaku mobilitas

\begin{tabular}{|c|c|c|c|}
\hline \multirow{2}{*}{ No } & \multirow{2}{*}{ Pekerjaan } & \multicolumn{2}{|c|}{ Anak } \\
\hline & & f & $\%$ \\
\hline 1 & 4 jam & 4 & 6 \\
\hline 2 & 5 jam & 11 & 16 \\
\hline 3 & 6 jam & 7 & 10,6 \\
\hline 4 & 7 jam & 32 & 48,4 \\
\hline 5 & 8 jam & 4 & 6 \\
\hline 6 & 9 jam & 4 & 6 \\
\hline 7 & $10 \mathrm{jam}$ & 4 & 6 \\
\hline & Jumlah & 66 & 100 \\
\hline
\end{tabular}

Sumber: Olahan data primer 
Sarana transportasi yang digunakan oleh anak untuk melakukan mobilitas yaitu dengan berjalan kaki, menggunakan sepeda dan sepeda motor. Tapi kebanyakan anak hanya berjalan kaki menuju sekolah, hal ini karena sekolah yang dituju tidak terlalu jauh dari tempat tinggal mereka.

Tabel 29. Sarana Transportasi mobilitas

\begin{tabular}{|c|l|c|c|}
\hline \multirow{2}{*}{ No } & \multirow{2}{*}{ Umur } & \multicolumn{2}{|c|}{ Anak } \\
\cline { 3 - 4 } & & $\mathbf{f}$ & $\mathbf{\%}$ \\
\hline 1 & Jalan kaki & 43 & 65,1 \\
\hline 2 & Sepeda & 13 & 19,7 \\
\hline 3 & Sepeda motor & 9 & 13,6 \\
\hline 4 & Kapal & 1 & 1,6 \\
\hline \multicolumn{2}{|c|}{ Jumlah } & 66 & 100 \\
\hline
\end{tabular}

Sumber: Olahan data primer

\section{SIMPULAN}

Berdasarkan penelitian yang telah dilakukan tentang karakteritik pelaku mobilitas di Kelurahan Sungai Piring, didapat kesimpulan sebagai berikut:

1. Karakteristik pelaku mobilitas kepala keluarga laki-laki adalah berada pada rentang usia 20-60 tahun, dengan jenis pekerjaan dominan sebagai petani, tingkat pendidikan umunya tamat SD. Mobilitas dilakukan karena alasan pekerjaaan, menuju ladang/kebun dengan durasi 5-10 jam sehari. Menggunakan sepeda, sepeda moor, mobil atau berjalan kaki. Jenis Mobilitas yang dilakukan adalah mobilitas harian dan mingguan.

2. Karakteristik pelaku mobilitas kepala keluarga perempuan adalah berada pada rentang usia 41-50 tahun. Dengan jenis pekerjaan sebagai IRT, PNS, petani dan pedagang. Dimana tingkat pendidikan umumnya tamat SD. Mobilitas dilakukan karena alasan pekerjaan dan memenuhi kebutuhan sehari-hari, menuju ladang, pasar, dan sekolah dengan durasi 2 sampai 8 jam. Jenis mobilitas yang dilakukan adalah mobilitas hariandan mingguan. Mobilitas dilakukan dengan menggunakan sepeda, sepeda motor dan jalan kaki.

3. Karakteristik istri pelaku mobilitas adalah berada pada usia 20 sampai 60 tahun, dengan jenis pekerjaan sebagai ibu rumah tangga, PNS, pegawai swasta, petani dan wiraswasta. Dimana tingkat pendidikan mulai dari tamat SD hingga tamat PT. Mobilitas dilakukan karena alasan pekerjaan dan memenuhi kebutuhan sehari-hari. arah tujuan mobilitas adalah sekolah, puskesmas, pasar, dan ladang. Dengan surasi mobilitas selama 2 jam sampai 9 jam. Sarana transportasi yang digunakan yaitu jalan kaki, sepeda dan sepeda motor. Dimana mobilitas yang dilakukan adalah jenis mobilitas harian dan mingguan.

4. Karakteristik anak sebagai pelaku mobilitas adalah berada pada rentang usia 7 tahun sampai 40 tahun, bekerja sebagai pelajar, petani, nelayan, pegawai swasta dan guru honor. Tingkat pendidikan anak yang melakukan mobilitas masih SD hingga masih Kuliah dan tamat SD hingga Tamat PT. Alasan anak melakukan mobilitas adalah karena pekerjaan dan pendidikan. Arah tujuan mobilitas anak adalah sekolah, ladang, dinas sosial dan kantor camat. Durasi mobilitas selama 4-10 jam. Jenis mobilitas yang dilakukan adalah mobilitas harian dan mingguan. Dimana sarana transportasi yang digunakan adalah jalan kaki, sepeda dan sepeda motor. 


\section{DAFTAR PUSTAKA.}

Hurst, Eliot M. E.1974. Geography 222 : Issues in Economic Geography; Course Notes: Issues and Landscapes. Washington, D.C.] : Distributed by ERIC Clearinghouse

Kamaluddin, Rustian, 1987. Beberapa aspek pembangunan nasional dan pembangunan daerah. Jakarta: Lembaga Penerbit, Fakultas Ekonomi, Universitas Indonesia

Mantra, Ida Bagoes.2013. Demografi Umum. Yogyakarta: Pustaka Pelajar

Miro, Fidel. 2002. Perencanaan Transportasi Untuk Mahasiswa, Perencana dan Praktisi. Jakarta: Erlangga

Peraturan Pemerintah Nomor 34 Tahun 2006 tentang Jalan

Sumaatmadja, N.(1981). Studi Geografi Suatu Pendekatan dan Analisis Keruangan. Bandung : Alumni

Sumardi,Mulyanto. 1982.Kemiskinan dan Kebutuhan Pokok.Jakarta: CV. Rajawali

Tamin, Ofyar Z. 2000. Perencanaan dan Permodelan Transportasi. Bandung : ITB

Tika, Pabundu. 1997. Metode Penelitian Geografi. Jakarta : Gramedia Pustaka Utama

Tukiran. 2002. Mobilitas penduduk Indonesia : tinjauan lintas disiplin. Jogjakarta : Pusat Studi Kependudukan dan Kebijakan, Universitas Gadjah Mada

UU No.34 tahun 2006 tentang Jalan 